Journal of Business Management and
Economic Research
2019, 3 (12) DOI: 10.29226/TR1001.2019.171
Journal Homepage: https://www.jobmer.org

\title{
BOARD ATTRIBUTES AND FINANCIAL RISK MANAGEMENT: MODERATING EFFECT OF OWNERSHIP STRUCTURE AMONG LISTED NON-FINANCIAL FIRMS IN KENYA
}

\section{Thomas Kiptanui Tarus*}

Department of Accounting and Finance, Moi University

tarus9116@gmail.com

(Corresponding author)

\section{Joel K Tenai}

Department of Accounting and Finance, Moi University

\begin{abstract}
The objective of this study was to examine whether ownership structure moderates the connection between board attributes and financial risk management in Kenya. The sample included 41 non-financial companies from 2010-2017. The hierarchical binary logistic regression was used to evaluate the interaction conditions of the hypothesis. The findings of the research revealed that the ownership structure had a positive and insignificant moderating effect on the connection between financial expertise of the board and financial risk management $(B=0.12, \mathrm{Q}>0.05)$ while independent board members and financial risk management was positively and significantly moderated by ownership structure $(\beta=0.75, \varrho<0.05)$. The study findings will be useful to investors who want to make investments in firms by understanding board attributes in relation to structure risk management. This research offers logical information, especially in the case of emerging economies, on the role of ownership structure in influencing financial risk management decisions.
\end{abstract}

Keywords: Board Independence, Board Financial Expertise, Board Attributes, Ownership Structure, Finacial Risk Management. 
Journal of Business Management and Economic Research (JOBMER), vol.3, issue.12, pp.1-20

\section{Introduction}

Existing corporate risk management theories tend to assume full knowledge about all relevant decision parameters. In reality, considering the complexity of companies and the fast-changing world economy, there's much more evidence to suggest that managers are actually struggling to comprehend their own exposures. According to (El-Masry et al., 2016) management of risk need to be supported by robust governance practices particularly in non-financial companies. This is because the management of risk is believed to be one of the main elements of corporate governance and the ultimate responsibility for efficient risk management lies with the board. Therefore, without the immediate assistance and participation of the board members, it will be difficult to create an efficient risk management policy (Abdul et al., 2013). The tenacity of good governance is to enhance organizational value by reducing financial risks, business risks, and operational risks. (Rashid \& Islam, 2008).

In their seminal study (Shleifer \& Vishny, 1997) they narrated that governance mechanisms are a simple agency perspective by understanding how investors are getting managers to give them a return from their investment. Echoing this, the study approach on management of risk is just as simple as the agency's view, merely by understanding how the principals as represented by the board members are getting executives to make risk management choices by employing hedging derivative instruments that maximize long term company value and thus maximizing the shareholders worth. Additionally, (Allayannis et al., 2012) revealed that hedging generates more value in firms with robust internal governance, however, such firms (Lel, 2012) use derivatives to diminish risk and maximize firm value whereas those with weak governance use derivatives selectively to satisfy managerial self-interest. Asghar et al., (2018) pointed out that compliance with governance mechanisms restricts management to channel their energies away from valuedestroying activities and into value-creating activities and ultimately shareholders' rights are protected. The board's decisions and actions should reflect the demands of the shareholders, which would include a sustainable growth of a business with an appropriate risk in order to attain a long-term return on the investment (Wood \& Zaichkowsky, 2004).

Ownership structure highlights the legitimacy of the proportion of owners in relation to stake in the company and has long been viewed as a relevant external control mechanism for monitoring the management behavior and choices affecting the board members (Haider \& Fang, 2016). However, the ownership structure functions is multidimensional, as the conduct and performance of owners rely not

only on the kinds of executives but also on industry and the institutional culture. The agency theory shows that ownership structure functions as a protection mechanism in aligning the activities and behavior of 
executives (Jensen \& Meckling, 1976). The availability of a multitude of hedging tools according to (Nance et al., 1993) are crucial in enhancing sustainable corporate risk management by businesses which ultimately have a beneficial effect on the shareholders' wealth creation. Markets have been distinguished by accelerated uncertainty of foreign exchange rates, interest rates, market prices for securities and prices of commodities and, as a result, businesses face rapid vulnerability towards a broad array of corporate risks. Shareholder expectations are growing on the management not only recognizing but properly handling the exposure of the firm (Bodnar \& Gebhardt, 1999) and because of managing risk, it has, therefore, become a firms' fundamental strategy. The concern that fascinates the study is whether the structure of shareholders in lieu of shares held plays a moderating role by shaping management choices on potential management of risk via the independent board members and board financial expertise. The objective of this study is, therefore, to investigate whether the ownership structure performs a significant moderating function in the interaction between board attributes and financial risk management.

\section{Review of the Theory}

The study research was guided by agency theory derived from the idea of separating ownershop from control. The agency's concerns according to (Jensen \& Meckling, 1976) extend to potential conflicts of interest between both the principal and the agent who is contracted by the principal to accomplish the obligation. In setting up a business, it reflects the division of controlling and ownership of the firm assets. Executives may participate in personal-dealing to maximize resources under their command and frequently undertake vanity projects which mostly boost their value. Shleifer \& Vishny, (1997) noted that there is a wealth of empirical evidence showing that agency costs in the corporation are genuine, pervasive and possibly significant. In this regard, the agency's management of risk disputes arises when the agent and the principal have distinct opinions on the quantity of residual risk to be borne by the company. According to (Smith \& Stultz, 1985), managers incline to be risk-averse than shareholders because a bigger portion of their wealth, including their human capital, is linked to the achievement and ongoing presence in the enterprise. In view of their command over working practices, managers have the capacity to set the threshold of risk that maximizes their own value, as opposed to the level that maximizes shareholder value (Jankensgård, 2019).

According to the agency theory (Fama, 1980), the presence of autonomous executives in the company narrows the issues relating to the agency by adequately tracking the conduct of managers. The theory indicates that potential conflicts among managers and stockholders of firms in relation to the inability of owners to perfectly monitor their managers may reduce the entities' net worth and hence negatively affect 
their value. It is therefore assumed that, due to the detachment of possession and control, agents may not be able to align their selfish driven interests within the company in line with the owners. Unless otherwise limited, executives will conduct self-serving actions that could be destructive to the monetary well-being of the principals (Rashid, 2016). However, agents will indeed be inspired to operate for the best interests of shareholders (Rashid et al., 2010) only when there is a managerial motivation to do so in the manner of board members who lays the benchmark for less self-interested actions of managers.

The theory as pointed by (Mayers \& Smith, 1987) expounds a probable discrepancy between owners, managers and debt holders owing to asymmetries in income distribution, which can result in taking the excessive risk by the firm. Agency theory continually shows that hedging policies have a significant impact on shareholder worth. The theory conveys strong support on hedging as a reaction to the divergence between managerial incentives and shareholders' concerns. To mitigate the agency's problems, Rose (2005) claims that the corporate board plays a main role in overseeing management and aligning its interests with the owners' desires. The board is regarded to be the main inner corporate governance mechanism (Brennan, 2006), as the board monitors and oversees management, and provides strategic direction to managers who can undertake the measures and ratify management plans (Jonsson, 2005).

Existing agency theory recommends a series of procedures aimed at reconciling the interests of shareholders and managers, through the application of internal control mechanisms by non-executive directors (Shleifer \& Vishny, 1986). The logical implication for corporate governance from the perspective of agency theory is that regulatory structures need to be implemented so as to protect cases of conflict of interest between the principal and the agent (Fama \& Jensen, 1983). Since corporate scandals and the development of new corporate governance codes, corporate risk management is often seen as a suitable component of the governance framework.

\section{Review of Literature and Development of Hypothesis}

\subsection{Board Financial Expertise and Financial Risk Management}

The collapse of multiple internal governance structures has often been quoted as the primary contributors to the global economic crisis between 2007 and 2008 (Bebchuk et al., 2010, Hashagen et al., 2009). However, entities that often lack the financial expertise of the members of the board played an important role in the crisis. It is imperative to note that financial expertise is essential in understanding the complex transactions of the company as well as the exposures linked with entities' plans. Furthermore, various company boards lacked adequate financial expertise in identifying and controlling the exposure levels (Srivastav \& 
Hagendorff, 2016). Therefore in this regard, it is prudent that directors' expertise, particularly to the financial knowledge, is vital for effective decision making by the board. It is the source of legitimacy and power that determines a director's contribution to board deliberations (Srivastav \& Hagendorff, 2016).

Management of risks is linked to a certain array of capabilities that managers might poses. Among the broad spectrum of skills that managers may have, Chhaocharia \& Grinstein (2007) proposed that financial literacy is crucial for any board to work efficiently. As a result, boards with a greater proportion of autonomous directors with financial knowledge are anticipated to handle business risks more efficiently by making less risky choices. Accordingly (Acharya et al., 2012) noted that financial expertise among board members inspires management in employing hedging derivative tools in alleviating against future uncertainties. In addition (Fama \& Jensen, 1983) argued that members of the board are mandated in administering the organization hence they are required to have an understanding of the entire organization which will enable them to execute their responsibilities flawlessly.

\section{H1: Board financial expertise does not significantly affect financial risk management}

\subsection{Board Independence and Financial Risk Management}

The literature on corporate governance broadly documents boards executives' independency as one of the effective ways in monitoring the management where board independence increases with the proportion of directors' independence on the board. Fama (1980) considers autonomous directors to be referees whose job is to guarantee that the board as the supreme internal monitoring for corporate decision-making and safeguarding the welfare of owners. In addition, Fama and Jensen (1983) noted that boards with a higher percentage of autonomous executives have significant control over managerial actions. Empirical evidence shows that the beneficial effect of an autonomous board on a wide spectrum of the board decisions tends to support the concept that the monitoring efficiency of the board improves with the percentage of independent outside directors. Farrar (2005) indicates that autonomous directors play a significant role in long term firm planning and risk mitigation processes. Fernandes (2008) further observed that companies with non-executive directors have fewer issues with the agency and better-aligned interests of shareholders and managers.

The respective corporate governance report, (OECD, 2004) emphasizes the importance of increased nonexecutive representation on boards implying that non-executives are likely to bring greater autonomy and objectivity to board decisions. The impact of the outside executives was explored by (Mardsen \& Prevost, 2005) in a sample of non-financial firms listed on the New Zealand Stock Exchange. They found that firms 
with increased growth potential as well as a larger percentage of external board members are less probable to employ hedging tools to handle exposures. They further examined the impact of the structure of ownership on block holders and insider shareholders but did not find any statistical significant findings indicating strong support for the utilization of hedging instruments. Additionally, the board independence was examined by Borokhovich et al., (2004) and the findings of the statistics revealed that the effect of independent external directors was statistically significant and positively relating to the management of corporate risk. In another study, (Dionne \&Trikki, 2013) centered on the percentage of autonomous directors on the boards, and the results disclosed a significant and positive connection between management of risk by firms and independence of the board implying that the board independence is an essential governance attribute.

\section{$H_{2:}$ Board independence does not significantly affect financial risk management}

\subsection{Moderating role of Ownership Structure between Board Attributes and Financial Risk Management}

It has been asserted by scholars like (Abraham \& Cox, 2007; Beattie et al., 2001) that the board attributes which in this study is represented by board independence and board financial expertise, as well as ownership structure, could have an impact on management of financial risks through the utilization of hedging instruments. The ownership structure according to (Razali \& Tahir, 2011) is characterized as the structure of the owners in terms of shares held. Shareholders with substantial stakes in the firm (Wright et al., 1996) can shape the structure of risk management, which can affect the ability of a company to compete and eventually survive in a complicated business setting. Variations in corporate governance play a significant role in the management of risk. In addition, Owusu-Ansah (1998) verified that the ownership structure and financial risk management link is explained by agency theory since modern corporations are differentiated by the detachment of ownership from control. In addition, Jensen \& Meckling (1976) argued that agency problems were declining when managerial ownership increased as the financial interests of corporate insiders and shareholders progressively converged.

The corporate governance frameworks and ownership structure jointly affect hedging behavior. The propensity of managers to hedge can be influenced by the corporate governance environment (Lel, 2006) as well as the ownership structure of companies (Tufano, 1996). Where protection is weak, managers tend to utilize hedging tools for their own advantage. When investors require greater transparency and better monitoring, the probability of the corporations to hedge increases (Lel, 2012). In addition, Hutson \& Stevenson (2010) found a negative association between creditors' rights and firms' exposure and that a 
good corporate governance environment enhances firms to involve in hedging actions. Allayannis et al., (2012) provide consistent evidence that tightly controlled businesses are much more inclined to be hedged with derivatives. Interestingly, Fauver \& Naranjo (2010) found that hedging has adverse valuation effects on companies with weaker corporate governance and lesser monitoring circumstances.

It is argued that ownership structure mitigates the free-riding issues of corporate control connected with a dispersed principal. In the same way, large shareholders have an incentive to exercise greater supervision and control over leadership in order to minimize agency issues and boost their oversight capacity in the entity where they invest. Demetz \& Lehn (1985) contend that executives' actions are less observable in firms experiencing a more uncertain environment and therefore the rewards of ownership are higher. According to Osuoha, (2013) he noted that the ownership concentration forms the choices of companies with respect to hedging operations. In this regard, the internal block holders of companies have distinct incentives than external block holders. Misalignment of interest amongst internal and external block members may lead companies to economic hazards (Allayannis et al., 2012). However, the utilization of derivative tools provides a suitable way in reducing risks faced by corporate entities and therefore it needs to be taken into consideration by managers who have been entrusted to run the company. The implications of using derivative instruments as a hedging mechanism enhance the value of corporate share price.

Similarly, Boubaker et al., (2010) determined the impact of the ownership concentration on the use of derivatives as a means of management risk. They discovered that the ownership concentration of companies had a significant effect on the choices of companies regarding the use of derivatives tools. The impact of family-controlled businesses in the use of derivatives was investigated by (Hagelin et al., 2006) and indeed the findings show that the largest shareholder in a family-owned and family-controlled business was significantly and negatively associated with corporate hedging. Spano (2007) argued that executives with a greater shareholding proportion were positively using derivatives to truncate risk in the best interests of shareholders.

The results of (Al-Shboul \& Alison, 2009) who studied institutional ownership impact on the ownership of managers by using hedging tools through the ownership structures revealed that institutional ownership is substantially and favorably related to foreign exchange derivatives, while directors ownership was not substantially associated to the utilization of derivatives in reducing foreign-exchange vulnerability. Conversely, Wang \& Fan (2011) revealed that internal block owners holding 5\% or more of the common stock in a business are negatively linked to the application of derivatives in reducing risks as they favor mitigating the risks by diversifying their portfolio in more than one business. Indeed, Whalley (2008) 
considered the effect of executive ownership on hedging and presented proof that managers positively use derivatives to hedge and improve the intrinsic value of their stock options, while stock ownership may not inspire them to just use derivatives, while Lel (2006) found no support between the block owners and management of corporate risk.

Ownership structure which is an external control mechanism, has not been discussed extensively in a board governance context. The effect of ownership structure and management of corporate risk is not very clear and it depends on the optimal balance between the costs incurred and benefits accrued on high ownership stakes (Paligorova, 2010). The agency's theory advocates that structure of ownership in the firm acts as a catalyst in mitigating the principal-agent conflict by better monitoring and control. It assumes that managers are risk-averse when working just as agents and protecting their own interests, while shareholders are risk-neutral because they can diversify their particular forms of risk. The concept of agency theory according to (Jensen \& Meckling, 1976) indicates that ownership structure has an impact on the management of risk via its influence on management decisions. In this context, the presence of large shareholders may affect the managers' financial decisions because they have the authority and resources to actively monitor and influence executives with the objective of maximizing the earnings. Likewise, institutional investors are more active in monitoring management when they are the major stockholders (Jiang \& Kim, 2015). In addition, from the institutional perspective (Laporta et al., 1997), noted that countries where investor's protection is weak, ownership structure acts as an effective outside control mechanism.

According to Laporta et al., (1999) ownership structure leads to expropriation of wealth by the majority shareholders. In a nation where the legal framework of minority shareholders interest protection is weak, controlling shareholders may divert corporate resources for their private advantage (Li et al., 2015). Consequently, where large shareholding exists, the standard principal-agent dispute may become a principal-principal dispute where the rights of minority shareholders may be expropriated by controlling shareholders (Filatotchev et al., 2013). In order to tackle this issue, autonomous managers are employed primarily to safeguard minority shareholders' interest (Young et al., 2008) and to retain controls and checks on the efficient functioning of the company. Hence, drawing from agency theory and empirical reviews, the study assumed that;

$\mathrm{H}_{1 \mathrm{a}} \quad$ Ownership structure does not moderate the link between board financial expertise and financial risk management. 
$\mathrm{H}_{2 b} \quad$ Ownership structure does not moderate the link between board independence and financial risk management.

\section{Conceptual framework}

Independent variable

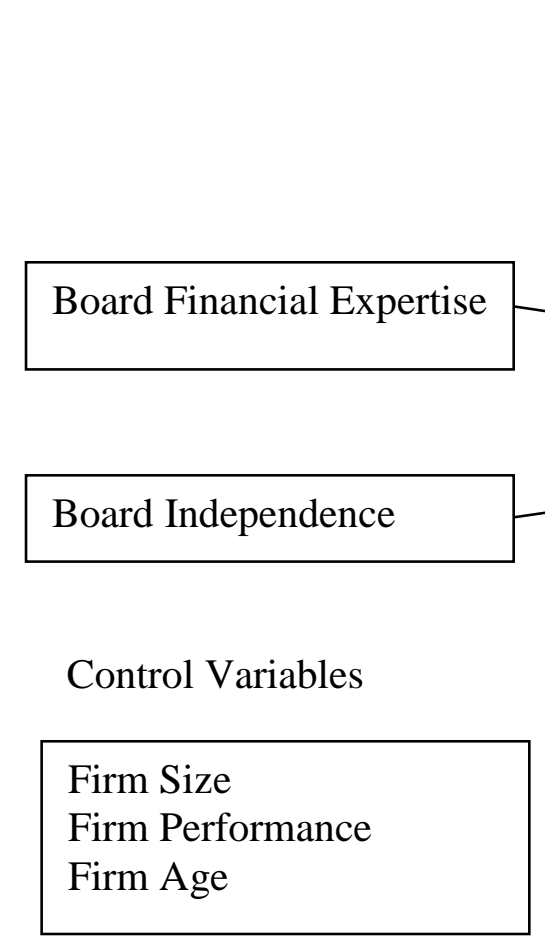

Moderating variable

Dependent variable

Financial Risk Management

Ownership Structure

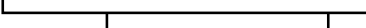

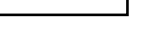



$\mathrm{H}_{2}$

Source: The Authors

\section{Material and methods}

This study used a longitudinal design with a positivist approach. The research focused solely on the attributes of the board, the ownership structure as the moderator and financial risk management as the outcome variable in determining whether there is any indication of the interaction on the link amongst the study variables. The sample of the study was 41 non-financial listed firms in Kenya from 2010-2017 giving a total of 328 firm-year observations. The document analysis guide was used to collect secondary data from the annual reports and audited financial statement which was sourced from capital market authority and downloaded from http://www.cmarcp.or.ke/index.php/financial-reports-accounts, companies' website and http://africanfinancials.com. Under International Accounting Standards 32 and 39, it is the requirement that the company must reveal the usage of financial derivative tools in their financial reports. 


\subsection{Variables Measurements}

Table 1: Variable Measurements

\begin{tabular}{|c|c|c|c|}
\hline Variables & Symbols & Measurement & Empirical Studies \\
\hline Dependent Variable & DV & & \\
\hline $\begin{array}{l}\text { Financial Risk } \\
\text { Management }\end{array}$ & FRM & $\begin{array}{l}\text { Dummy variables } 1 \text { for hedgers } \\
\text { users and } 0 \text { for non-hedgers }\end{array}$ & Géczy et al., (1997). \\
\hline Independent Variable & IV & & \\
\hline Board Financial Expertise & $\mathrm{BFE}$ & $\begin{array}{l}\text { The number of members of the } \\
\text { board with financial experience. }\end{array}$ & Minton et al., (2014) \\
\hline Board Independence & BI & $\begin{array}{l}\text { The proportion of directors' } \\
\text { independence divided by the total } \\
\text { number of directors on the board. }\end{array}$ & $\begin{array}{l}\text { Ferreira \& \& } \\
\text { Kirchmaier, (2013) }\end{array}$ \\
\hline Moderator & M & & \\
\hline Ownership Structure & OS & $\begin{array}{l}\text { Percentage of stocks held by the top } \\
5 \text { largest shareholders over total } \\
\text { shares. }\end{array}$ & $\begin{array}{l}\text { Demsetz \& } \\
\text { Villalonga, (2001) }\end{array}$ \\
\hline Control Variables & $\mathrm{C}$ & & \\
\hline Firm Size & FS & Natural log of total assets. & Laeven et al., (2014) \\
\hline Firm Performance & $\mathrm{FP}$ & Measured as ROA & (Chen et al., 2005) \\
\hline Firm Age & FA & $\begin{array}{l}\text { Total number of years a company } \\
\text { has been in operation since } \\
\text { registration. }\end{array}$ & Yasuda, (2005) \\
\hline
\end{tabular}

\subsection{Data analysis and Econometric model}

A panel data framework was used and the study employed the hierarchical binary logistic regression to test the hypothesis because the kind of the data of the outcome variable is non-linear 1 for hedgers and 0 for non-hedgers hence Peng et al., (2002) recommend that logistic regression is appropriate for analyzing 
non-linear data. By following (Fok et al., 1997) logistic regression analysis was used to establish the interaction of ownership structure on the association between board attributes and financial risk management and the following equation was estimated:

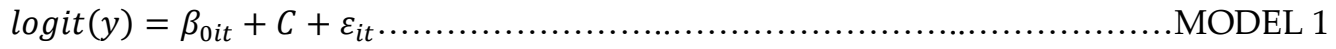

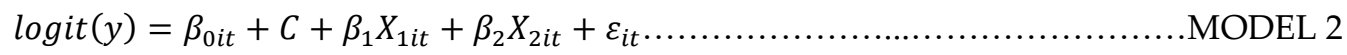

$$
\begin{aligned}
& \operatorname{logit}(y)=\beta_{0 i t}+C+\beta_{1} X_{1 i t}+\beta_{2} X_{2 i t}+\beta_{3} M_{3 i t}+\varepsilon_{i t} \ldots \ldots \ldots \ldots \ldots \ldots \ldots \ldots \ldots \ldots \ldots \text { MODEL } 3 \\
& \operatorname{logit}(y)=\beta_{0 i t}+C+\beta_{1} X_{1 i t}+\beta_{2} X_{2 i t}+\beta_{3} M_{3 i t}+\beta_{4} X_{1 i t} * M+\varepsilon_{i t} \ldots \ldots \ldots \ldots \ldots \ldots \text {. MODEL } 4 \\
& \operatorname{logit}(y)=\beta_{0 i t}+C+\beta_{1} X_{1 i t}+\beta_{2} X_{2 i t}+\beta_{3} M_{3 i t}+\beta_{4} X_{1 i t} * M+\beta_{5} X_{2 i t} * M+\varepsilon_{i t} \ldots \text { MODEL } 5
\end{aligned}
$$

Where,

$\beta_{0 i t}=$ The constant of equation, $C=$ Control variables (firm size, firm performance, and firm age), $X_{1 i t}=$ Board financial expertise, $X_{2 i t}=$ Board independence, $M=$ Ownership structure, $\beta_{1}-\beta_{5}=$ Coefficient of estimates, $\varepsilon_{i t}=$ Error term and $\operatorname{logit}(y)=$ Likelihood of utilizing hedging instruments used in this study to measure financial risk management.

\section{Results}

\subsection{Descriptive Statistics}

The statistical results revealed that management of corporate risk which is a practice of creating a company's economic value by using financial instruments to manage firm exposures and hedge against uncertainties was at a mean of 0.49 , the standard deviation of 0.50 , Skewness of 0.05 and kurtosis of 1.00 . The statistics findings demonstrate that approximately 49 percent of firms have adopted financial derivative instruments as the risk management tools, implying that the usability of hedging instruments was relatively low in the study which was used as a proxy of management of corporate risk by Kenyan non-financial listed firms.

Table 1: Descriptive Results of Study Variables

\begin{tabular}{lccccccc}
\hline Stats & Obs & Min & Max & Mean & SD & Skewness & Kurtosis \\
\hline Corporate Risk Management & 327 & 0 & 1 & 0.49 & 0.50 & 0.05 & 1.00 \\
Board Financial Expertise & 327 & 0 & 4 & 0.67 & 0.78 & 1.42 & 5.19 \\
Board Independence & 327 & 1.1 & 4.24 & 0.46 & 1.01 & 0.77 & 8.95 \\
Ownership concentration & 327 & 0.15 & 5.61 & 2.70 & 1.59 & 2.21 & 9.14 \\
Firm Size & 327 & 2.11 & 2.42 & 2.27 & 0.06 & 0.12 & 3.09 \\
Firm Performance & 327 & -6.78 & 1.96 & -3.09 & 1.37 & -0.64 & 3.90
\end{tabular}




\begin{tabular}{llllllll} 
Firm Age & 327 & 8.69 & 49.27 & 27.50 & 0.91 & 1.08 & 3.63 \\
\hline
\end{tabular}

Source: The authors

\subsection{Testing of hypothesis}

The moderating effect was tested in a series of hierarchical blocks in Table 2. In model 1, the control variables were tested which included firm size, firm performance and firm age. In model 2, predictor variables were tested and ownership structure which is a moderator was also tested so as to establish the contribution in model 3. The interaction terms in models 4 and 5 between board financial expertise* ownership structure and board independence*ownership structure were hierarchically tested.

The first hypothesis $\mathrm{H}_{1}$ showed that board financial expertise had a positive and significant effect on the outcome variable $(\beta=0.73, p<0.05)$. The implication is that an increase in the financial expertise of the board brings about better management of risks by marginal change of 0.73 . Board professional experience is a key determinant of boards' ability to make firm strategic decisions regarding hedging mechanisms

The second hypothesis $\mathrm{H}_{2}$ indicated that board independence had a negative and statistically significant effect on financial risk management $(\beta=-1.25, \mathrm{p}<0.01)$. The implication is that an increase in the number of board members is a deterrent to management of risks in the firm. The reason behind this could be that board members' independence may have a preference for the diversification of their investment portfolios in more than one firm with the goal of decreasing risk and maximizing the returns.

The third hypothesis $\mathrm{H}_{1}$ indicated that ownership structure does not moderate the interaction between the financial expertise of the board and financial risk management. The regression coefficient value for the interaction exerted a positive value on management of risks but the influence was not statistically significant based on the coefficient of estimates $\beta=0.12$ and $p$-value greater than 0.05 . The results indicated that ownership structure had a positive and no significant moderating effect on the link between the financial expertise of the board and management of risk. Owing to the insignificant p-value, the hypothesis was therefore not rejected. Therefore board financial expertise does not significantly moderate the relationship between the predictor variable and financial risk management.

The fourth hypothesis $\mathrm{H}_{2 \mathrm{~b}}$ stated that ownership structure does not moderate the association between board independence and financial risk management. From the statistical findings, it was evident that the regression coefficient of the interaction term of ownership structure on the association between board independence and financial risk management was at $(\beta=0.75, \varrho<0.05)$. The results suggest that ownership structure positively and significantly moderates the interaction between the predictor and the outcome 
variable hence the hypothesis was therefore rejected. The implication is that the ownership structure brings about greater utilization of derivatives in protecting shareholders' interest and enhancing shareholders' value.

The hierarchical binary logistic regression findings disclosed a rise in Pseudo $\mathrm{R}^{2}$ with the addition of variable blocks. For instance, the control factors (firm size, firm performance and firm age) contributed to Pseudo $\mathrm{R}^{2}$ of $2 \%$. With the addition of predictor variables in model 2, they jointly contribute to Pseudo $\mathrm{R}^{2}$ of $20 \%$ (Pseudo $\mathrm{R}^{2}$ change of $18 \%$ ). The statistical results revealed that board financial expertise had a positive coefficient and statistically significant at p-value less than $5 \%$ while board independence had a negative coefficient and statistically significant at $p$-value less than $1 \%$.

When ownership structure which is the moderator in model 3 was introduced to the model, the Pseudo ${ }^{2}$ increased to $26 \%$ (Pseudo $\mathrm{R}^{2}$ change of $8 \%$ ) which was statistically significant $(\mathrm{p}<0.05)$. However, when ownership structure was moderated with board financial expertise in model 4, it was evident that the interactions were positive and insignificant at the $p$-value of more than $5 \%(p>0.05)$. The Pseudo $\mathrm{R}^{2}$ change of board financial expertise was minimal at $1 \%$ (increase in Pseudo $\mathrm{R}^{2}$ from $26 \%$ to $27 \%$ ). The addition of the interaction of ownership structure in model 5 positively moderates the association between board independence and financial risk management and the Pseudo $\mathrm{R}^{2}$ increased to $31 \%$ (Pseudo $\mathrm{R}^{2}$ change of $4 \%$ ) which was statistically significant at $\mathrm{p}<0.05$. The general model of moderation showed that Pseudo $\mathrm{R}^{2}$ improved from 26 percent to 31 percent, suggesting that the structure of the shareholders in terms of shareholdings shapes the choices of companies on hedging operations. This is in line with the results of Wright et al., (1996), which concluded that shareholders with substantial stakes in a firm can shape the nature of their risk management, which may influence the capacity of a company to compete and ultimately its survival. 
Table 2: Hierarchical Logistic Regression



Standard error statistics in parentheses, ${ }^{* *} \mathrm{p}<0.01,{ }^{*} \mathrm{p}<0.05$.

The graphical analysis in Figure 2 revealed a strong significant effect on financial risk management when the board independence and ownership structure is on high levels, small significant effect on financial risk management when the board independence and ownership structure is on medium levels and no significant effect on financial risk management when the board independence and ownership structure is on low levels. This indicates that as board independence increases, ownership becomes well-structured and thus the board is able to manage financial risks well via utilization of hedging instruments. 


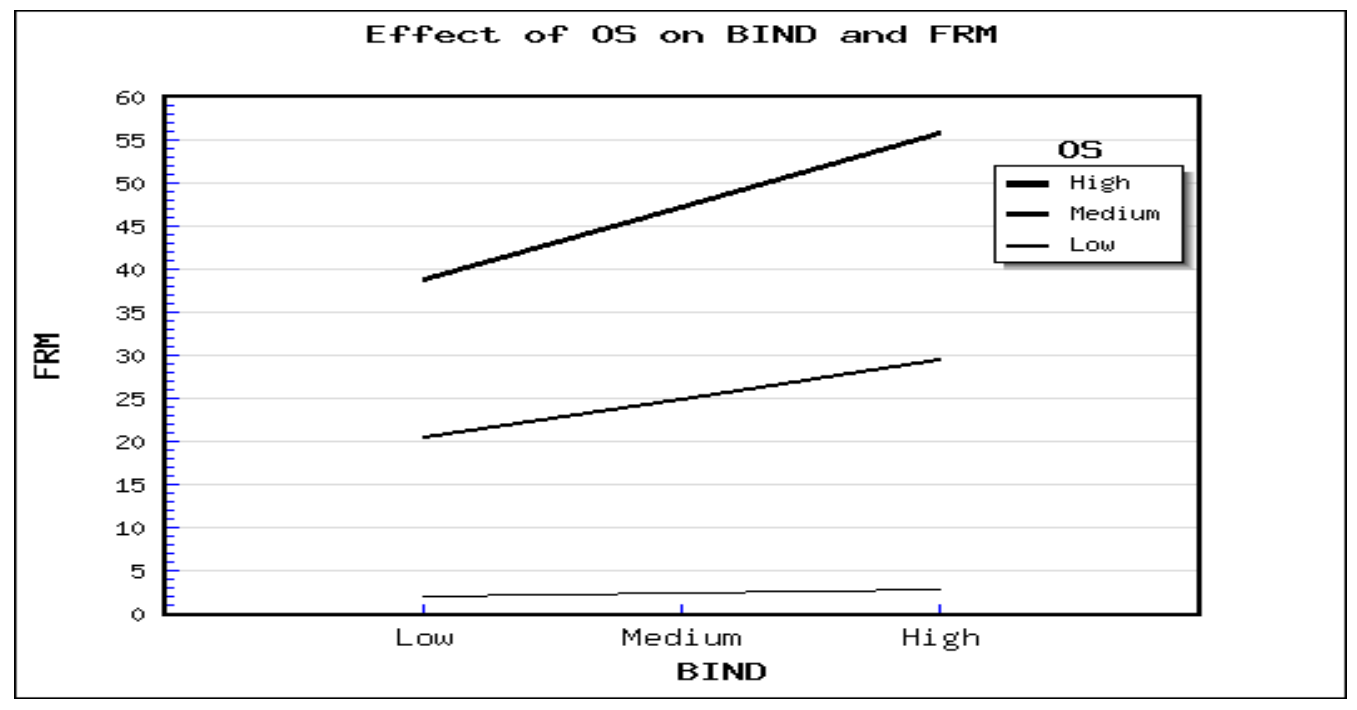

Source: Research Data (2019)

Figure 2: Mod graph for the moderating effect of ownership structure on the relationship between board independence and financial risk management

\section{Discussion, Conclusion and Recommendation}

Board professional experience is a key determinant of boards' ability to make firm strategic decisions regarding hedging mechanisms as it improves the risk management of non-financial listed firms. The results suggested that members of a board who are financially knowledgeable have better ideas of the sophisticated hedging tools involved in risk management activities hence they engage more actively in hedging the firm's exposure in enhancing shareholder's worth. However, the study did not find evidence of any moderating role of ownership structure in the relationship between board financial expertise and financial risk management. The insignificance of the moderating role of the structure of ownership has shown the lack of relevance of the role of the structure of the shareholders in terms of shareholding in the connection between the financial expertise of the board and corporate risk management. Based on the findings, ownership structure directly affects financial risk management but does not play any moderating role in the relationship.

Board independence caused a negative and significant effect on financial risk management. The results suggested that a high proportion of outside directors was detrimental to hedging activities. This is so because non-executive directors have a tendency to diversify their portfolios in more than one firm hence, they are unlikely to be at the forefront in the use of hedging instruments in mitigating exposures. However, the direction of the relationship between board independence and financial risk management changes with 
the incorporation of the ownership structure as the moderating variable. This, however, indicated that ownership structure moderates the link between board independence and financial risk management. It is clear that whenever there are shareholders with a significant stake in a firm, the decision is made to capitalize on the use of financial derivatives to manage risk is enhanced. This shows that with highly structured ownership, the effect of board independence on financial risk management is positively enhanced.

Thus, the idea that ownership structure plays a role in firm decisions becomes even more evident with the finding that firm risk rises with the increase in the proportion of structured ownership (Dhillon \& Rossetto, 2014). This is an indication that the research of the connection between the ownership structure and the risk management should not be restricted to the differentiation between firms with and without concentration ownership systems or to the connection between the fractions of stocks owned by the biggest concentrated ownership. The ownership structure is an important element that plays an active role in firm policy. This new approach offers the alternative of re-examining and re-interpreting many aspects of firm policies related to corporate governance. It is essential that regulators pursue policies that limit the structure of ownership in order to limit the likelihood of adverse effects on minority shareholders

The research offers helpful ideas for regulators and policymakers from the view of external governance in a developing economy such as Kenya, where investor protection is relatively weak and capital markets are still developing, structured ownership affects the decisions made by companies and eventually the potential risk of a company, irrespective of its board independence and financial expertise. These results provide a solid basis for further research on how to improve the supervisory roles of boards so that they can evaluate management decisions objectively in order to enhance the value of shareholders.

\section{References}

Abdul Rahman, R., Noor, S. and Ismail, T.H., 2013. Governance and risk management: Empirical evidence from Malaysia and Egypt. International Journal of Finance \& Banking Studies, 2(3), pp.21-33.

Abraham, S. and Cox, P., 2007. Analyzing the determinants of narrative risk information in UK FTSE 100 annual reports. The British Accounting Review, 39(3), pp.227-248.

Acharya, V., Engle, R. and Richardson, M., 2012. Capital shortfall: A new approach to ranking and regulating systemic risks. American Economic Review, 102(3), pp.59-64.

Allayannis, G., Lel, U. and Miller, D.P., 2012. The use of foreign currency derivatives, corporate governance, and firm value around the world. Journal of International Economics, 87(1), pp.65-79.

Al-Shboul, M. and Alison, S., 2009. The Effects of the Use of Corporate Derivatives on the Foreign Exchange Rate Exposure. Journal of Accounting, Business \& Management, 16(1). 
Asghar Butt, A., Nazir, M., Arshad, H., and Shahzad, A., 2018. Corporate Derivatives and Ownership Concentration: Empirical Evidence of Non-Financial Firms Listed on Pakistan Stock Exchange. Journal of Risk and Financial Management, 11(3), p.33.

Beattie, V., Goodacre, A., Pratt, K. and Stevenson, J., 2001. The determinants of audit fees-Evidence from the voluntary sector. Accounting and Business Research, 31(4), pp.243-274.

Bebchuk, L.A., Cohen, A. and Spemann, H., 2010. The wages of failure: Executive compensation at Bear Stearns and Lehman 2000-2008. Yale J. on Reg., 27, p.257.

Bodnar, G.M. and Gebhardt, G., 1999. Derivatives usage in risk management by US and German nonfinancial firms: A comparative survey. Journal of International Financial Management $\mathcal{E}$ Accounting, 10(3), pp.153-187.

Borokhovich, K.A., Brunarski, K.R., Crutchley, C.E. and Simkins, B.J., 2004. Board composition and corporate use of interest rate derivatives. Journal of Financial Research, 27(2), pp.199-216.

Boubaker, S., Mefteh, S. and Shaikh, J.M., 2010. Does ownership structure matter in explaining derivatives' use policy in French listed firms. International Journal of Managerial and Financial Accounting, 2(2), pp.196-212.

Brennan, N., 2006. Boards of directors and firm performance: is there an expectations gap?. Corporate Governance: An International Review, 14(6), pp.577-593.

Chen, Z., Cheung, Y.L., Stouraitis, A., and Wong, A.W., 2005. Ownership concentration, firm performance, and dividend policy in Hong Kong. Pacific-Basin Finance Journal, 13(4), pp.431-449.

Chhaochharia, V. and Grinstein, Y., 2007. The changing structure of US corporate boards: 1997-2003. Corporate Governance: An International Review, 15(6), pp.1215-1223.

Demsetz, H. and Lehn, K., 1985. The structure of corporate ownership: Causes and consequences. Journal of political economy, 93(6), pp.1155-1177.

Demsetz, H. and Villalonga, B., 2001. Ownership structure and corporate performance. Journal of corporate finance, 7(3), pp.209-233.

Dhillon, A. and Rossetto, S., 2014. Ownership structure, voting, and risk. The Review of Financial Studies, 28(2), pp.521-560.

Dionne, G. and Triki, T., 2013. On risk management determinants: What really matters?. The European Journal of Finance, 19(2), pp.145-164.

El-Masry, A.A., Elbahar, E. and Abdel-Fattah, T., 2016. Corporate governance and risk management in GCC Banks. Corporate Ownership and Control, 13(3), pp. 8-16.

Fama, E.F. and Jensen, M.C., 1983. Separation of ownership and control. The journal of law and Economics, 26(2), pp.301-325.

Fama, E.F., 1980. Agency problems and the theory of the firm. Journal of political economy, 88(2), pp.288-307.

Farrar, J.H., 2005. Corporate governance: theories, principles and practice (Vol. 2). Melbourne: Oxford University Press.

Fauver, L. and Naranjo, A., 2010. Derivative usage and firm value: The influence of agency costs and monitoring problems. Journal of Corporate Finance, 16(5), pp.719-735. 
Fernandes, N., 2008. EC: Board compensation and firm performance: The role of "independent" board members. Journal of multinational financial management, 18(1), pp.30-44.

Ferreira, D. and Kirchmaier, T., 2013. Corporate boards in Europe: size, independence and gender diversity. Boards and Shareholders in European Listed Companies: Facts, Context and Post-Crisis Reforms, pp.191-224.

Filatotchev, I., Jackson, G. and Nakajima, C., 2013. Corporate governance and national institutions: A review and emerging research agenda. Asia Pacific Journal of Management, 30(4), pp.965-986.

Fok, R.C., Carroll, C. and Chiou, M.C., 1997. Determinants of corporate hedging and derivatives: A revisit. Journal of Economics and Business, 49(6), pp.569-585.

Géczy, C., Minton, B.A. and Schrand, C., 1997. Why firms use currency derivatives. The Journal of Finance, 52(4), pp.1323-1354.

Hagelin, N., Holmén, M. and Pramborg, B., 2006. Family ownership, dual-class shares, and risk management. Global Finance Journal, 16(3), pp.283-301.

Hagelin, N., Holmén, M., Knopf, J.D. and Pramborg, B., 2007. Managerial stock options and the hedging premium. European Financial Management, 13(4), pp.721-741.

Haider, J. and Fang, H.X., 2016. Board size, ownership concentration and future firm risk. Chinese Management Studies, 10(4), pp.692-709.

Hashagen, J., Harman, N., Conover, M. and Sharma, J., 2009. Risk management in banking: Beyond the credit crisis. The Journal of Structured Finance, 15(1), pp.92-103.

Hutson, E. and Stevenson, S., 2010. Openness, hedging incentives and foreign exchange exposure: A firmlevel multi-country study. Journal of International Business Studies, 41(1), pp.105-122.

Jankensgård, H., 2019. Does Managerial Power Increase Selective Hedging? Evidence from the Oil and Gas Industry. Journal of Risk and Financial Management, 12(2), p.71.

Jensen, M.C. and Meckling, W.H., 1976. Theory of the firm: Managerial behavior, agency costs and ownership structure. Journal of financial economics, 3(4), pp.305-360.

Jiang, F. and Kim, K.A., 2015. Corporate governance in China: A modern perspective.

Jonsson, E.I., 2005. The role model of the board: A preliminary study of the roles of Icelandic boards. Corporate Governance: An International Review, 13(5), pp.710-717.

Kirkpatrick, G., 2009. The corporate governance lessons from the financial crisis. OECD Journal: Financial Market Trends, 2009(1), pp.61-87.

La Porta, R., López de Silanes, F., Shleifer, A. and Vishny, R., 1999. Corporate Ownership Around the World The Journal Of Finance.

Laeven, L. and Levine, R., 2009. Bank governance, regulation, and risk taking. Journal of financial economics, 93(2), pp.259-275.

Laporta, R., Lopes-De-Silanes, F., Shleifer, A. and Vishny, W. R. 1997, "Legal Determinants of External Finance", The Journal of Finance, (3), 1131-1150.

Lel, U., 2012. Currency hedging and corporate governance: a cross-country analysis. Journal of Corporate Finance, 18(2), pp.221-237. 
Li, K., Lu, L., Mittoo, U.R. and Zhang, Z., 2015. Board independence, ownership concentration and corporate performance-Chinese evidence. International Review of Financial Analysis, 41, pp.162175.

Marsden, A. and Prevost, A.K., 2005. Derivatives use, corporate governance, and legislative change: an empirical analysis of New Zealand listed companies. Journal of business finance $\mathcal{E}$ accounting, 32(1-2), pp.255-295.

Mayers, D. and Smith Jr, C.W., 1987. Corporate insurance and the underinvestment problem. Journal of Risk and Insurance, pp.45-54.

Minton, B.A., Taillard, J.P. and Williamson, R., 2014. Financial expertise of the board, risk taking, and performance: Evidence from bank holding companies. Journal of Financial and Quantitative Analysis, 49(2), pp.351-380.

Nance, D.R., Smith Jr, C.W. and Smithson, C.W., 1993. On the determinants of corporate hedging. The journal of Finance, 48(1), pp.267-284.

OECD, O., 2004. The OECD principles of corporate governance. Contaduría y Administración, (216).

Osuoha, J.I., 2013. Financial Engineering, Corporate Governance and Nigeria Economic Development. Journal of Financial Risk Management, 2(04), p.61.

Owusu-Ansah, S., 1998. The impact of corporate attributes on the extent of mandatory disclosure and reporting by listed companies in Zimbabwe. The International Journal of Accounting, 33(5), pp.605-631.

Paligorova, T., 2010. Corporate risk taking and ownership structure (No. 2010, 3). Bank of Canada Working Paper.

Peng, C.Y.J., Lee, K.L. and Ingersoll, G.M., 2002. An introduction to logistic regression analysis and reporting. The journal of educational research, 96(1), pp.3-14.

Rashid, A., 2016. Managerial ownership and agency cost: evidence from Bangladesh. Journal of business ethics, 137(3), pp.609-621.

Rashid, A., De Zoysa, A., Lodh, S. and Rudkin, K., 2010. Board composition and firm performance: Evidence from Bangladesh. Australasian Accounting, Business and Finance Journal, 4(1), pp.76-95.

Rashid, K. and Islam, S.M., 2008. Corporate Governance and Firm Value: Econometric Modeling and Analysis of Emerging and Developed Financial Markets. Emerald Group Publishing.

Razali, A.R., and Tahir, I.M., 2011. Review of the literature on enterprise risk management. Business management dynamics, 1(5), p.8.

Rose, C., 2005. The composition of semi-two-tier corporate boards and firm performance. Corporate Governance: An International Review, 13(5), pp.691-701.

Shleifer, A., Vishny RW (1997). A Survey of Corporate Governance". Journal of Finance, 52(2), pp.737-783.

Shleifer, A., \& Vishny, R. W. (1986). Large shareholders and corporate control. Journal of political economy, 94(3, Part 1), 461-488.

Smith, C.W. and Stulz, R.M., 1985. The determinants of firms' hedging policies. Journal of financial and quantitative analysis, 20(4), pp.391-405. 
Spanò, M., 2007. Managerial ownership and corporate hedging. Journal of Business Finance E Accounting, 34(7-8), pp.1245-1280.

Srivastav, A. and Hagendorff, J., 2016. Corporate governance and bank risk-taking. Corporate Governance: An International Review, 24(3), pp.334-345.

Tufano, P., 1996. Who manages risk? An empirical examination of risk management practices in the gold mining industry. The Journal of Finance, 51(4), pp.1097-1137.

Wang, X. and Fan, L., 2011. The determinants of corporate hedging policies. International Journal of Business and Social Science, 2(6), pp.29-38.

Whalley, A.E., 2008. Effect of Executive Share Ownership and Private Hedging on Executive Stock Option Exercise and Values. Warwick Business School. Available online: http://www.warwick.ac.uk/fac/soc/wbs/subjects/finance/faculty1/elizabeth_whalley/esohedging. pdf

Wood, R., and Zaichkowsky, J.L., 2004. Attitudes and trading behavior of stock market investors: A segmentation approach. The Journal of Behavioral Finance, 5(3), pp.170-179.

Wright, P., Ferris, S.P., Sarin, A. and Awasthi, V., 1996. Impact of corporate insider, blockholder, and institutional equity ownership on firm risk taking. Academy of Management Journal, 39(2), pp.441458.

Yasuda, T., 2005. Firm growth, size, age and behavior in Japanese manufacturing. Small Business Economics, 24(1), pp.1-15.

Young, M.N., Peng, M.W., Ahlstrom, D., Bruton, G.D. and Jiang, Y., 2008. Corporate governance in emerging economies: A review of the principal-principal perspective. Journal of management studies, 45(1), pp.196-220. 